\title{
PENGARUH KOMPENSASI, MOTIVASI DAN KEPUASAN KERJA TERHADAP KOMITMEN PEGAWAI KELURAHAN SAWAHAN, KECAMATAN PONJONG, KABUPATEN GUNUNGKIDUL
}

\author{
Syaif Abdullah \\ Fakultas Ekonomi Universitas Sarjanawiyata Tamansiswa \\ syaif7214.sa@gmail.com
}

\begin{abstract}
This study aimed to examine the effect of Compensation, Motivation, and Job Satisfaction Employee Commitment Against Urban Sawahan Village, District Ponjong, Gunungkidul, Yogyakarta. Another objective of this study was to determine the effect of compensation on the commitment, motivation influence on commitment, influence job satisfaction and commitment to the simultaneous effect of compensation, motivation, job satisfaction on commitment. This study uses a quantitative approach with a survey method in which data is collected using a questionnaire. The primary data in this study were obtained from 30 Employees Sawahan Village, District Ponjong, Gunungkidul, Yogyakarta .

Analytical tool in this study is multiple regression, to see the effect of compensation, motivation, and job satisfaction on commitment. The results of the analysis of multiple regersi $\mathrm{Y}=-0.020+$ $0.666 \mathrm{X} 1 \mathrm{X} 2-0.028 \mathrm{X} 3$, indicating that the compensation does not affect the commitment

( -0.020 ), positively affect motivation to commitment ( 0.666 ), and job satisfaction has no effect on commitment ( -0.028 ). Simultaneously compensation, motivation, and job satisfaction have a significant effect ( 0.003$)$ on the commitment.

Keywords : compensation, motivation, job satisfaction, commitment.
\end{abstract}

\section{A. Pendahuluan}

\section{a. Latar Belakang Masalah}

Sumber Daya Manusia (SDM) merupakan seluruh kemampuan atau potensi penduduk yang berada di dalam suatu wilayah tertentu beserta karakteristik atau cirri demografis, social maupun ekonominya yang dapat dimanfaatkan untuk keperluan pembangunan. Jadi membahas sumber daya manusia berarti membahas penduduk dengan segala potensi atau kemampuannya yang terdiri atas aspek kualitas dan kuantitas.

Pada dunia bisnis, manusia merupakan aset terpenting dalam mendukung kinerja perusahaan. Sebagaimana kita ketahui bahwa tenaga kerja memegang peranan penting dalam meningkatkan produktivitas sebuah perusahaan. Moeheriono (2009) menyatakan bahwa keberhasilan suatu organisasi dengan berbagai ragam kinerja tergantung kepada kinerja seluruh anggota organisasi itu sendiri. Unsur individu manusialah yang memegang peranan paling penting dan menentukan keberhasilan lembaga, lembaga pemerintahan Desa misalnya. Kelurahan Sawahan merupakan Lembaga Pemerintahan di daerah Kecamatan Ponjong, Kabupaten Gunungkidul.

Di karenakan di lingkup Kelurahan Sawahan jarang adanya penelitian tentang hal tersebut, maka Kepala Desa menginginkan adanya penelitian mengenai pengaruh kompensasi, motivasi, dan kepuasan kerja terhadap komitmen pegawai Kelurahan Sawahan.

\section{B. Rumusan Masalah}

Berdasarkan latar belakang tersebut, perumusan masalah dalam penelitian ini sebagai berikut: 
1. Apakah kompensasi berpengaruh terhadap komitmen pegawai Kelurahan Sawahan?

2. Apakah motivasi berpengaruh terhadap komitmen pegawai Kelurahan Sawahan ?

3. Apakah kepuasan kerja berpengaruh terhadap komitmen pegawai Kelurahan Sawahan?

4. Apakah kompensasi, motivasi, kepuasan kerja secara simultan berpengaruh pada komitmen pegawai Kelurahan Sawahan.

\section{Tinjauan Teori}

a. Kompensasi

$$
\text { Panggabean }
$$

mengungkapkan bahwa kompensasi adalah semua jenis penghargaan yang berupa uang atau bukan uang yang diberikan kepada pegawai secara layak dan adil atas jasa mereka dalam mencapai tujuan perusahaan. Tujuan pemberian kompensasi terhadap karyawan agar perusahaan dapat menarik, mendorong, dan mempertahankan karyawan agar tetap bekerja di perusahaan dan dapat berproduktivitas tinggi. Penghargaan menjembatani kesenjangan antara tujuan organisasi dengan aspirasi serta pengharapan karyawan.

Selanjutnya, Flippo

mengemukakan bahwa kompensasi menunjukkan balas jasa yang adil dan layak diberikan kepada pekerja atas jasa-jasanya dalam mencapai tujuan perusahaan. Supaya efektif, kompensasi seharusnya dapat (Cascio, 1995 sebagaimana dikutip oleh Panggabean, 2004):

a. Memenuhi kebutuhan dasar,

b. Mempertimbangkan adanya keadilan eksternal,

c. Mempertimbangkan adanya keadilan internal, dan

d. Pemberiannya disesuaikan dengan kebutuhan individu Menurut Mangkuprawira (2011a), kompensasi merupakan sebuah komponen penting dalam hubungannya dengan karyawan.
Kompensasi sangat dipengaruhi oleh faktor-faktor internal dan eksternal perusahaan. Kompensasi juga sangat dipengaruhi oleh tekanan-tekanan faktor pasar kerja, posisi rebut tawar kolektif, peraturan pemerintah, filosofi manajemen puncak tentang pembayaran dan manfaat termasuk tantangan dari kompensasi internasional.

b. Motivasi

Menurut Arep dan Tanjung (2003) motivasi adalah self concept realization yaitu merealisasikan konsep dirinya. Self concept realization bermakna bahwa seseorang akan selalu termotivasi jika : (1). Ia hidup dalam suatu cara yang sesuai dengan peran yang lebih ia sukai, (2). Diperlukan sesuai dengan tingkatan yang lebih ia sukai dan (3). Dihargai sesuai dengan cara yang mencerminkan penghargaan seseorang atas kemampuannya. Ada tiga hal yang diperhatikan yaitu peran, perlakuan, dan penghargaan.

Manfaat motivasi yang utama adalah menciptakan gairah kerja sehingga produktivitas kerja meningkat. Setiap individu mempunyai tujuan yang berbeda satu sama lain, diantara hal yang diiinginkan dari tiap individu dapat dikemukakan sebagai berikut :

a. Kompensasi yang sesuai

b. Lingkungan yang nyaman

c. Kesempatan untuk maju

d. Penghargaan dari pihak lain

\section{1) Teori Kebutuhan Maslow}

Hersey dan Blanchard (1994) mengemukakan teori kebutuhan. Pada dasarnya faktor utama pendorong seseorang untuk melakukan suatu kegiatan adalah kebutuhan. Model Maslow sering disebut dengan model hierarki kebutuhan. Kebutuhan seseorang harus dipenuhi agar dia termotivasi untuk bekerja. Berdasarkan hierarki Maslow, Arep dan Tanjung (2003) mengemukakan 
kebutuhan manusia pada dasarnya tidak pernah dapat terpenuhi secara keseluruhan, karena terdapat tingkatan kebutuhan pada setiap individu. Setelah kebutuhan pada tingkat tertentu telah terpenuhi, maka seseorang akan berusaha untuk menggapai kebutuhan tingkat berikutnya. Dorongan dalam diri karyawan dalam mencapai tingkat kebutuhan selanjutnya dapat dimanfaatkan perusahaan atau organisasi sebagai motivator untuk meningkatkan kinerja.

c. Kepuasan Kerja

Menurut Rivai dan Jauvani (2010), kepuasan kerja pada dasarnya merupakan sesuatu yang bersifat individual. Setiap individu memiliki tingkat kepuasan yang berbeda-beda sesuai dengan sistem nilai yang berlaku pada dirinya. Makin tinggi penilaian terhadap kegiatan yang dirasakan sesuai dengan keinginan individu maka makin tinggi kepuasannya terhadap kegiatan tersebut. Dengan demikian kepuasan merupakan evaluasi yang menggambarkan seseorang atas perasaan sikapnya senang atau tidak senang, puas atau tidak puas dalam bekerja.

Menurut Rivai dan Jauvani (2010), teori tentang kepuasan kerja adalah :
a. Teori
ketidaksesuaian
(Discrepancy theory)
Teori ini mengukur kepuasan kerja seseorang dengan menghitung selisih antara sesuatu yang seharusnya dengan kenyataan yang dirasakan. Apabila kepuasannya diperoleh melebihi dari yang diinginkan maka orang akan menjadi lebih puas lagi sehingga terdapat dicrepancy positif.
b. Teori keadilan (Equity theory)

Teori ini mengemukakan bahwa orang akan merasa puas atau tidak puas tergantung pada ada atau tidak adanya keadilan (equity) dalam suatu situasi, khususnya situasi kerja. Menurut teori ini komponen utama dalam teori keadilan adalah input, hasil, keadilan dan ketidakadilan. Input adalah faktor bernilai bagi karyawan yang dianggap mendukung pekerjaannya, seperti: pendidikan, pengalaman, kecakapan, jumlah tugas dan peralatan atau perlengkapan yang digunakan untuk melaksanakan pekerjaannya. Hasil adalah sesuatu yang dianggap bernilai oleh seorang karyawan yang diperoleh dari pekerjaannya seperti : upah/gaji, keuntungan sampingan, simbol, status, penghargaan dan kesempatan untuk berhasil atau aktualisasi diri. Menurut teori ini, setiap karyawan akan membandingkan rasio input hasil dirinya dengan rasio input hasil orang lain. Bila perbandingan itu cukup adil maka karyawan akan merasa puas. Bila perbandingan itu tidak seimbang tetapi menguntungkan bisa menimbulkan kepuasan, tetapi bisa pula tidak. Tetapi bila perbandingan itu tidak seimbang akan timbul ketidakpuasan.

\section{c. Komitmen Pegawai}

Menurut Mangkuprawira (2009), komitmen berarti ada suatu tindakan, dedikasi, dan kesetiaan seseorang pada janji yang telah dinyatakannya untuk memenuhi tujuan organisasi dan individunya. Budaya kerja dalam organisasi diaktualisasikan sangat beragam. Bisa dalam bentuk dedikasi atau loyalitas, tanggung jawab, kerja sama, kedisiplinan, kejujuran, ketekunan, semangat, mutu kerja, keadilan, dan integritas kepribadian. Menurut Mangkuprawira (2011a), semua bentuk aktualisasi budaya kerja itu sebenarnya bermakna komitmen. 
Semakin tinggi derajat komitmen karyawan, semakin tinggi pula kinerja yang dicapainya. Bentuk komitmen karyawan bisa diwujudkan antara lain dalam beberapa hal berikut:

a. Komitmen dalam mencapai visi, misi, dan tujuan organisasi.

b. Komitmen dalam melaksanakan pekerjaan sesuai dengan prosedur kerja standar organisasi.

c. Komitmen dalam mengembangkan mutu sumber daya manusia bersangkutan dan mutu produk.

d. Komitmen dalam mengembangkan kebersamaan tim kerja secara efektif dan efisien.

Allen dan Meyer (1993) sebagaimana dikutip oleh Panggabean (2004) mendefinisikan komitmen organisasi sebagai sebuah konsep yang memiliki tiga dimensi, yaitu:

a. Affective commitment adalah tingkat seberapa jauh seorang karyawan secara emosi terikat, mengenal, dan terlibat dalam organisasi. Karyawan dengan affective commitment yang tinggi tetap tinggal dengan organisasi karena mereka mau. Orang-orang ini mengenal organisasi dan terikat untuk tetap menjadi anggota organisasi untuk mencapai tujuan organisasi.

b. Normative commitment merujuk kepada tingkat seberapa jauh seseorang secara psikologikal terikat untuk menjadi karyawan dari sebuah organisasi yang didasarkan kepada perasaan seperti kesetiaan, afeksi, kehangatan, pemilikan, kebanggaan, kesenangan, kebahagiaan, dan lain-lain. Mereka yang memiliki normative commitment yang tinggi tetap tinggal karena mereka merasa seharusnya melakukan demikian.

c. Continuance commitment adalah suatu penilaian terhadap biaya yang terkait dengan meninggalkan organisasi. Mereka yang memiliki continuance commitment yang tinggi tetap tinggal dalam organisasi karena mereka butuh untuk berbuat demikian. Mereka tetap tinggal karena mereka akan mendapatkan uang pensiun, fasilitas, dan senioritas, atau mereka harus membayar biaya karena pindah kerja.

\section{Hipotesis}

Berdasarkan uraian pada latar belakang dan pokok permasalahan diatas, maka dapat ditarik suatu hipotesa sebagai berikut :

H1 :Kompensasi berpengaruh signifikan terhadap komitmen pegawai Kelurahan Sawahan

H2 :Motivasi berpengaruh signifikan terhadap komitmen pegawai Kelurahan Sawahan

H3 :Kepuasan kerja berpengaruh signifikan terhadap komitmen pegawai Kelurahan Sawahan

H4 :Kompensasi, motivasi, kepuasan kerja secara simultan berpengaruh terhadap komitmen pegawai Kelurahan Sawahan

\section{E. Metode Penelitian}

a. Populasi dan Sampel

Populasi dalam penelitian ini adalah Pegawai Kelurahan Sawahan yang berjumlah 30 pegawai. Dalam menentukan ukuran sampel, dilakukan dengan mempertimbangkan pendapat yang dikemukakan oleh Arikunto (2006), yaitu: untuk sekedar ancer-ancer maka apabila subyeknya kurang dari 100, lebih baik diambil semua sehingga penelitiannya merupakan penelitian populasi. Pengambilan sampel menggunakan metode sensus atau sampel total.

b. Metode Pengumpulan Data a. Kuesioner 
Memberikan daftar pertanyaan atau quisioner kepada pegawai Kelurahan Sawahan. Kuesioner yang disusun menggunakan modifikasi metode skala likert lewat prosedur penskalaan summated ratings yang terdiri dari lima jawaban yaitu:

1) STS : Sangat Tidak Setuju dengan nilai 1

2) TS : Tidak Setuju dengan nilai 2

3) CS : Cukup Setuju dengan nilai 3

4) $\mathrm{S}$ : Setuju dengan nilai 4

5) SS : Sangat Setuju dengan nilai 5

c. Teknik Analisis Data

Regresi berganda digunakan untuk mengetahui pengaruh variabel bebas terhadap variabel terikatnya secara bersama-sama.

\section{F. Hasil dan Pembahasan}

Hasil dari regresi berganda dalam penelitian ini menunjukan bahwa variabel bebas yang digunakan dalam penelitian ini hanya mempengaruhi variabel terikat sebesar 0,348. Hal ini menunjukan bahwa $65,2 \%$ faktor lain yang dapat mempengaruhi komitmen pegawai kelurahan desa Sawahan seperti lingkungan kerja, fasilitas kerja dll. Selain itu dengan melihat table coefficients kita dapat mengetahui hasil regresi berganda dalam bentuk persamaan yaitu $\mathrm{Y}=-0,020 \quad \mathrm{X}_{1}+$ $\begin{array}{lllll}0,666 & X_{2} & -0,028 & X_{3} & \text { yang berarti bahwa }\end{array}$ variabel kompensasi tidak mempengaruhi komitmen sebesar -0,020; variabel motivasi mempengaruhi komitmen sebesar 0,666; variabel kepuasan kerja mempengaruhi komitmen sebesar $-0,028$. Untuk menjawab permasalahan yang ada dapat diketahui hasil dari analisis sebagai berikut:

1. Permasalahan 1: Apakah kompensasi berpengaruh terhadap komitmen pegawai Kelurahan Sawahan?

Hasil pengujian hipotesis 1 menunjukan bahwa kompensasi tidak mempengaruhi komitmen sebesar 0,020 dengan tingkat signifikansi
0,894>0,05 yang artinya variabel kompensasi tidak berpengaruh terhadap komitmen. Oleh karena itu dalam penelitian ini kompensasi sama sekali tidak berpengaruh terhadap komitmen, ini tidak sesuai dengan penelitian sebelumnya yang dilakukan oleh Penelitian yang di lakukan oleh Sasmitha, Stevanus Bayu Gilang ( 2009 ) menunjukan bahwa terdapat pengaruh yang sangat signifikan antara kompensasi dengan komitmen.

Namun pada penelitian ini kompensasi tidak berpengaruh pada komitmen, tentunya ada variabel lain yang mempengaruhinya. Seperti di sampaikan oleh Brockner and Siegel dalam Kelley M. Pennington (1991) bahwa para pegawai dengan dengan kompensasi yang sesuai dan kepercayaan tinggi akan mendukung dan berkomitmen pada organisasi. Hal ini memberi dugaan bahwa tidak adanya pengaruh pada variabel kompensasi karena adanya variabel lain yang muncul seperti variabel kesesuaian kompensasi.

2. Permasalahan 2: Apakah motivasi berpengaruh terhadap komitmen pegawai Kelurahan Sawahan?

Hasil pengujian hipotesis 2 menunjukan bahwa motivasi mempengaruhi komitmen sebesar 0,666 dengan tingkat signifikansi $0,004<0,05$ nilai ini yang paling tertinggi di antara variabel lain yang artinya variabel motivasi berpengaruh terhadap komitmen. Dapat diartikan semakin tinggi motivasi yang di berikan maka semakin tinggi pulan komitmen pegawai tersebut, jadi para pegawai akan betah bekerja di Kantor Kelurahan Sawahan jika mereka di berikan motivasi tinggi oleh Kepala Desa. Hal ini sesuai dengan penelitianPenelitian yang di lakukan oleh Tella, et al. (2007) menunjukan bahwa adanya hubungan antara motivasi dengan komitmen organisasi. 
Motivasi dapat meningkatkan kinerja dan kepuasan kerja sehingga dapat meningkatkan komitmen organisasional. Penelitian lain di lakukan oleh Warsi , et al. (2009) juga menemukan bahwa ada hubungan antara motivasi dengan komitmen organisasi. Artinya ada pengaruh antara motivasi dan komitmen organisasional.

Motivasi para pegawai Kelurahan Sawahan bermacam macam, seperti para pegawai sangat di hargai dalam pekerjaanya, pekerjaanya di akui oleh Kepala Desa, dan pegawai juga mendapatkan pengawasan maksimal dari Kepala Desa dalam bekerja. Selain itu pemenuhan kebutuhan hidup juga dapat di jadikan motivasi untuk para pegawai, terutama kebutuhan jasmaninya yang dapat di penuhi dengan pengahasilan yang mereka dapatkan.

Pegawai kelurahan bertahan di kantor Kelurahan Sawahan saat ini di karenakan mereka berfikir tidak ada pekerjaan lain selain bekerja di Kantor Kelurahan Sawahan yang dapat menjamin kelayakan hidup mereka yang di nilai dari pendapatan mereka. Dengan kata lain, motivasi yang kuat berpengaruh terhadap komitmen yang kuat pula.

3. Permasalahan 3: Apakah kepuasan kerja berpengaruh terhadap komitmen pegawai Kelurahan Sawahan?

Hasil pengujian dari hipotesis 3 menunjukan bahwa variabel kepuasan kerja tidak mempengaruhi komitmen sebesar -0,028 dengan tingkat signifikansi $0,893<0,05$ yang artinya variabel kepuasan kerja tidak berpengaruh terhadapap komitmen. Penelitian ini tidak sesuai dengan penelitian sebelumnya yang di lakukan oleh Ayeni dan Popoola (2007) dalam Warsi, Fatima, dan Sahibzada (2009) di peroleh hasil bahwa ada hubungan antara kepuasan kerja dengan komitmen organisasi. Menurut mereka, kepuasan kerja menentukan sejauh mana organisasi menemukan dan memenuhi harapan karyawan. Penelitian lain yang di lakukan oleh Daneshfard dan Ekvanian (2012) menemukan adanya hubungan langsung secara signifikan antara kepuasan kerja dengan komitmen organisasi disebabkan oleh fasilitas dan lingkungan kerja. Artinyaada pengaruh yang signifikan antara kepuasan kerja dengan komitmen organisasi.

Sama seperti kompensasi, kepuasan kerja di duga membutuhkan kepercayaan yang kuat, sedangkan kepercayaan akan tumbuh jika para pegawai di berikan janji (kepuasan kerja akan di dapatkansecara berkelanjutan). Seperti di ungakapkan Barnes (2003) kepercayaan melibatkan seseorang untuk bertingkah laku tertentu (komitmen) karena keyakinan bahwa mitranya akan memberikan apa yang ia harapkan, dan suatu harapan yang umumnya di miliki adalah bahwa kata, janji dan pernyataan orang lain dapat di percaya. Hal ini mengindikasikan, janji jika kepuasan kerja akan di penuhi secara berkelanjutan maka komitmen akan bertambah.

4. Permasalahan4:Apakah kompensasi, motivasi, kepuasan kerja secara simultan berpengaruh pada komitmen pegawai Kelurahan Sawahan?

Hasil uji $\mathrm{F}$ dengan sifnifikansi $0.003<0,05$ sehingga dapat dikatakan bahwa secara serentak variabel bebas kompensasi, motivasi, dan kepuasan kerja berpengaruh terhadap variabel terikat komitmen. Dengan kata lain jika kompensasi, motivasi, dan kepuasan kerja terpenuhi maka akan mempengaruhi komitmen pegawai. Dari hasil regresi berganda dalam bentuk persamaan yaitu $\mathrm{Y}=-0,020 \mathrm{X}_{1}+$ $0,666 \quad X_{2} \quad-0,028 \quad X_{3}$. Kompensasi mempengaruhi komitmen sebesar - 
0,020 dengan tingkat signifikansi $0,894>0,05$ yang artinya variabel kompensasi tidak berpengaruh terhadap komitmen. Sedangkan variabel motivasimempengaruhi komitmen sebesar 0,666 dengan tingkat signifikansi $0,004<0,05$ nilai ini yang paling tertinggi di antara variabel lain yang artinya variabel motivasi berpengaruh komitmen. Dan variabel kepuasan kerja mempengaruhi komitmen sebesar $-0,028$ dengan tingkat signifikansi $0,893>0,05$ yang artinya variabel kepuasan kerja tidak berpengaruh terhadap komitmen.

\section{G. REFERENSI}

Arep Ishak dan Hendri Tanjung. 2003. Manajemen Motivasi. Jakarta: Gramedia Widiasarana Indonesia.

Arikunto. 2006. Prosedur Penelitian Suatu Pendekatan Praktik. Jakarta: Rhineka Cipta

Carraher S.M dan Carraher. S.C. 2006. Human Resources Issues Among Smes In Eastern Europe: A 30 month study In Belarus, Poland, and Ukraine. International journal of entrepreneurship. Cullowhee: Vol.10.

Flippo B. E. 1994. Manajemen Personalia, Edisi Keenam Jilid 1. Terjemahan Moh. Masud. Jakarta: Gelora Aksara Pratama.

Hasibuan Malayu .S.P. 1993. Manajemen Sumberdaya Manusia: Dasar dan Kunci Keberhasilan. Jakarta: Haji Masagung.

Hersey P dan K. Blanchard. 1994. Manajemen Perilaku Perusahaan: Pendayagunaan Sumber Daya Manusia, Terjemahan Agus Dharma. Jakarta: Erlangga.

Igalens dan J. Roussel, P. 1999. A Study Of The Relationships Between Compensation Package, Work Motivation and Job Satisfaction. Journal of Organizational Behavior. Chichester. Vol. 20.

Kuswadi. 2004. Cara Mengukur Kepuasan Karyawan. Jakarta: Penerbit Elex Media Komputindo.
Luthans F. 1998. Organization Behavior. Singapore: Mc. Graw Hill Book, Inc.

Mangkuprawira Tb. S. 2003. Manajemen Sumber Daya Manusia Strategik. Jakarta: Ghalia Indonesia.

Mangkuprawira Tb. S. 2009. Horison: Bisnis, Manajemen, dan Sumberdaya Manusia. Bogor: IPB Press.

Mangkuprawira Tb. S. 2011a. Manajemen Sumber Daya Manusia Strategik (Edisi Kedua). Bogor: Ghalia Indonesia.

Mangkuprawira Tb. S. 2011b. Strategi Efektif Mengelola Karyawan. Bogor: Penerbit IPB Press.

Moeheriono. 2009. Pengukuran Kinerja Berbasis Kompetensi. Bogor: Ghalia Indonesia.

Panggabean Mutiara S. 2004. Manajemen Sumber Daya Manusia. Bogor Selatan: Ghalia Indonesia.

Pennington, Kelly M.,1991. Motivational Factors For Mental Healt Workers As Related to Intrinsic Motivation, Trust and Commitment. Loyola University of Chicago

Riduwan. 2004. Metode dan Teknik Menyusun Tesis. Alfabeta. Bandung

Rivai Veithzal dan Jauvani, E.S. 2010. Manajemen Sumber Daya Manusia Untuk Perusahaan (dari Teori ke Praktik). Jakarta: Raja Grafindo Persada. Santoso, Singgih, 2000, Buku Latihan SPSS Statistik Parametrik, PT Elex Media Komputindo, Jakarta.

Sigit, Soehardi. 2003. Pengantar Metodologi Penelitian Sosial-BisnisManajemen, Cetakan Ketiga, Yogyakarta: Penerbit Bagian Penerbitan Fakultas Ekonomi Universitas Sarjanawiyata Tamansiswa

Simamora H. 1995. Manajemen Sumber Daya Manusia.Yogyakarta: Bagian Penerbitan Sekolah Tinggi Ilmu Ekonomi YKPN.

Sekaran, Uma, edisi 4 ( 2006 ). Metode penelitian untuk bisnis

Penerbit salemba empat.

Shasmitha, Stevanus Bayu Gilang, Simanjutak, James. 2009. Komitmen 


\section{JURNAL MANAJEMEN VOL 5 NO.1 JUNI 2015}

Organisasi, Motivasi dan Kompensasi. Jakarta: Program Studi Manajemen Fakultas Ekonomi Unika Atma Jaya.

Tella, adeyinka. 2007. "Work Motivation, Job Satisfaction, an Organisational Comitment'. Journal of Library Philosophy and Practice. Nigeria (April) Vol. 7
Warsi, Sundas, Noor Fatima, and Shamim A. Sahibzada. 2009. Study on Relationship Bettwen Organizational Comittment and Determinants Among Private Sector Employees of Pakistan. Islamabad: International Review of Business Research Paper Vol. 5 No. 3 